\title{
Career plateauing and work attitudes: Moderating effects of mentoring others with Nigerian employees
}

Samuel O. Salami

Department of guidance and counselling, Kampala International Univeristy, Uganda

\begin{abstract}
This study examined the relation of career plateauing to job satisfaction, organizational commitment and turnover intentions and the moderating effects of mentoring on the relationships between career plateauing and the three dependent variables. Data were collected from 280 government employees in Nigeria who were more than 30 years old and came from a wide variety of organizations. Results of this study showed that career plateauing was negatively correlated with job satisfaction and organizational commitment and positively correlated with turnover intentions. Hierarchical multiple regression analyses indicated that mentoring played a significant moderating role on the relationships between career plateauing and job satisfaction and turnover intentions. Based on the findings, the implications, limitations of this study and direction for future research are discussed.
\end{abstract}

Keywords: mentoring, career plateau, job satisfaction, organizational commitment, turnover intentions.

\section{Introduction}

As organizational structures become more horizontal, nowadays career advancement in terms of vertical promotion has become competitive and difficult (Jung \& Talk, 2008). Consequently, most employees often reach a career plate au before attaining their career goals. Career plate au is not a new phenomenon; however, the issue of concern is the rate at which it is becoming widespread in many organizations (Ongori \& Agolla, 2009). Many scholars on organizational careers are of the view that career plateau is fast becoming a critical managerial and organization issue 
that needs to be managed properly to avoid employees' discontent (Bucke \& Mikkelsen, 2006). Because of changes in the business environment, restructuring, downsizing and employment equity, career plateaving will likely become one of the most important career issues of the next decade.

Career plateau is defined as the point in one's career at which the likelihood of additional hierarchical promotion is very low or impossible (Ongori \& Agolla, 2009). Bardwick (1986) identified two types of career plateaving: (a) structural (hierarchical) plateauing and (b) content (job content) plateauing. Hierarchical plateauing results when there is little chance of further vertical movement within an organization whereas job content plateauing occurs when individuals are no longer challenged by their job or job responsibilities, and there is overall staleness of the job itself. Burke and Mikkelsen (2006) distinguished between three types of career plateauing: structural, content and life plateaus. Life plateauing refers to an individual's feeling of being trapped or stuck in their roles outside of work. The focus of the research literature has been on hierarchical plateauing (McCleese, Eby, Scharlau \& Hoffman, 2001) while job content and life plateauing have received much less attention (McCleese \& Eby, 2007). Career plateau has been used as antecedent to many undesirable work outcomes such as low satisfaction, high stress, poor performance, withdrawal symptoms, low organizational commitment and increased turnover intention (Heilmann, Holt \& Rilovick, 2008). Career plateau has the potential to cause discomfort among the employees because lack of continued upward progression is regarded a yardstick to measure employees' performance (Ongoni \& Agolla, 2009). However, there is no unanimous agreement in the literature on the negative influence of career plateau on employees' work attitudes. For example, Palmero, Roger and Tremblay (2001) found no significant difference in terms of general satisfaction between respondents already at a career plateau and those who did not reach this stage. Clark (2005) argued that a plateau can be a positive influence upon an employee in the sense that he or she no longer faces uncertainty in the form of changing and/or increased responsibilities. Such a position may lead to contentment, security and job comfort.

Thus far, the literature on the relationship between career plateau and work attitudes includes a variety of contradictory conclusions about the attitudes of those who have attained career plateau and those who have not (Xie \& Long, 2008). However, the empirical study on consequences of the career plateau is scarce generally and particularly in Nigeria. Hence, this study focused on three possible consequences of career plateau: job satisfaction, organizational commitment and turnover intention. Given the negative consequences associated with career plateauing such as job dissatisfaction, lack of organization commitment and 
turnover intentions, employers will need to know how to avoid career plateauing among their older workers.

Research on career plateau has focused on types of career plateau, their measurements, antecedents (Armstrong-Stassen, 2008) and consequences (Tremblay, Roger \& Toulouse, 1995). Little empirical research has been reported on the roles of moderators on the relationship between career plateau and work outcomes (Ettington, 1998). Studying the variables that moderate an individual's reactions to reaching career plateau (work attitudes) may be a step forward in understanding this process in organizations and in searching for solutions in terms of managing human resources in a more effective way.

This study also addressed a neglected issue in the career plateau literature: few studies have examined the moderating role of mentoring (Lentz, 2004; Lentz \& Allen, 2009; Jung \& Tak, 2008). Some authors (Ettington, 1998; Milliman, 1992; Palmero et al., 2001 ) argued that the reactions to career plateau can be more or less pronounced depending on the types of jobs, organizational contexts, and individual characteristics. Previous research on moderating variables between career plateau and work attitudes includes job characteristics such as job enrichment potential, variety, autonomy, role ambiguity or participation in decision making. Aside from their direct impact on attitudes and behaviours, an interaction between these $\checkmark$ ariables and career plate au is expected to determine employees' reactions (Roger \& Tremblay, 2009; Tremblay \& Roger, 2004). Some studies also investigated the impact of individual factors such as stage of life, career aspiration, career motivation, perceived supervisor support and mentoring (Jung \& Tak, 2008; Lentz, 2004; Milliman, 1992). Individuals react in different ways when they are on a career plateau but some factors are expected to limit a fair number of the negative consequences associated with reaching that stage. This study thus examined the moderating role of mentoring experience on the relationship between career plateauing and work attitudes. The purpose of this study was to examine the relationship between career plateaving and work attitudes (job satisfaction, organizational commitment and turnover intention). Also this study was designed to examine the effects of mentoring on the relationship between career plateaving and work attitudes.

Career plateaving and work attitudes

A number of theoretical arguments and related empirical findings reinforce the contention that a direct link exists between career plateaving and work attitudes. Career plateauing has both negative effects and positive effects on work attitudes. 
Circumstances under which negative effects are found for career plateauing are when an employee feels he or she has the talent, skills, experience and initiative to advance beyond the current position but the company or establishment has no available positions or lacks equal confidence in the employee's ability in order to promote the employee. Such situation may lead to stress, frustration, dissatisfaction, intention to leave the organization and absenteeism (Jung \& Tak, 2008). Career plateau has been found to be significantly associated with reduced job performance (Lentz, 2004), decreased job satisfaction (Jung \& Tak, 2008; Lee, 2004; Lentz \& Allen, 2009; McCleese \& Eby, 2006; Palmero, Roger \& Tremblay, 2001; Xie \& Long, 2008), reduced organizational commitment (Jung \& Tak, 2008; Lentz, 2004; McCleese \& Eby, 2006) and increased turnover intentions (Heilmann, Holt \& Rilovick, 2008; Lentz, 2004). Despite the dysfunctional effects of career plateauing, there is evidence to suggest that such negativities may lead to optimism from the perspective of employees. For example, some researchers have found that some plateaved employees maintain the same level of productivity, do not appear bored and have high satisfaction with their jobs because acquiring new skills places them in a better position for other career opportunities elsew here (Ongori \& Agolla, 2009).

Positive effects of career plateauing are found when an employee no longer faces the problems of changing and/or increased responsibilities. Such a position may lead to contentment and security. For example, an employee who perceives low needs for career mobility may be afraid of the lifestyle required from someone at a higher level of management or the employee may underestimate the value of promotion regardless of his or her aptitude. Employees may be satisfied with their present positions in the organization and as such may prefer to improve the security of their present job and prefer it to the challenge of a higher level. The lifestyle of the community the employees belong to - that is friends, relatives or spouses (in the case of working couples) - may hamper the employees' aspirations. Relatives living in the same area or the career of the spouse could have a significant negative impact on the career mobility of an individual (Feldman \& Weitz, 1988). In addition, career plateaved employees could strive to improve their skills, acquire new qualifications and look for a higher position job outside their current organization. Also, career plateaved employees may have higher job performance and job satisfaction when they do not see themselves as plate aued (Ettington, 1998).

Ettington (1998) defined successful career plateauing as effective job performance and high satisfaction despite a low likehood of promotion. She found that objectively plateaved managers were more successful i.e. had higher job performance and higher job satisfaction when they did not see themselves as plateaved. They were more satisfied when they had challenging work but did not 
see themselves as technical or functional specialists. Furthermore, Maimunah (2008) reported that some employees hope to attain career plateau because they could not cope with constraints and stress that advancement imposes. The period of plateau can also be a highly desirable period of rest and security that provides an opportunity to recharge the energy and digest new ideas. Some employees believe that a plateau can be healthy for professionals, particularly those who have not attained a breakthrough in their careers (Kreuter, 1993).

Empirical studies reviewed above showed that the effects of career plateauing on the employees' work attitudes could be both positive and negative. As such, research on this issue is not concluded and should continue. There is need for further research on the relationship between career plateauing and employees' work attitudes. This is why the present study becomes warranted. Based on the empirical studies reviewed, it is expected that career plateauing will be negatively related to job satisfaction, and organizational commitment, and positively related to turnover intentions.

Mentoring and work attitudes

The mentoring relationship can be defined as an interpersonal experience between a junior and a senior employee, in which the senior employee (mentor) supports, guides, and orients the junior employee (protégé) through the various tasks, functions and culture within the organization (Kram, 1985). The benefits of having or being a mentor have received ample attention in research (Lankau \& Scandura, 2002). For example, studies showed that employees who have mentors or who are mentors report more promotions, have higher motivation, earn higher incomes, and score higher on work satisfaction than employees without a mentor or who are nonmentors (Ragins, Cotton \& Miller, 2000). Other studies revealed that employees with mentoring experience showed higher organizational commitment (Allen, Eby, Proteet, Lentz \& Lima, 2004; Lankau \& Scandura, 2002; Lentz, 2004; Ragins et al., 2000), decreased intention to turnover (Lentz, 2004; Lentz \& Allen, 2009) and increased job performance (Lentz,2004; Levenson, Van der Ste de \& Cohen,2006).

Research on the benefits of the mentoring relationship for mentors has not been as extensive as for mentees (Ragins \& Scandura, 1999). According to Fowler (2002), benefits for mentors were professional enhancement, organizational and peer recognition, interpersonal relationship, meaningfulness and fulfillment and productivity. Other benefits for mentors include: career enhancement, increased intelligence/information, having the mentee as a trusted advisor and feeling of pride (Zey, 1991). Allen, Poteet and Burroughs (1997) identified some benefits of mentoring 
for mentors which comprise: building support networks, self-satisfaction and satisfaction in seeing others grow and succeed and also general satisfaction in helping others; helping the mentor do his or her job, increasing the mentor's own learning/knowledge, and increasing the mentor's organizational visibility; ensuring the passage of knowledge to others and building a competent workforce.

Ragins and Scandura (1999) identified rewarding experience, job performance, loyal base of support, recognition by others and generativity as benefits of mentoring for mentors. Levinson (1978) discussed the growth and development that occurred for mentors. Recently, Allen, Evans, Ng and Dubios (2008) and Underhill (2008) conducted meta-analytic studies on the effectiveness of mentoring and found that mentoring had significant favourable effects on behavioural, attitudinal, healthrelated, relational, motivational and career outcomes. Burke (1984) and Burke and Mckeen (1997) were of the view that increased self-confidence, personal insight, learning how to deal with people and problems and fulfillment of psychosocial needs were some valuable outcomes. Allen, Lentz and Day (2003) and Bozionelos (2004) found that individuals who provided mentoring experience reported a higher current salary, greater rate of promotion, and higher perception of career success. However, some researchers found no significant relationship between mentoring and intentions to turnover (Allen et al., 2004) and job performance (van Emmerik, 2008). The inconsistencies in the results of studies that investigated the relationship between mentoring and work attitudes make this study warranted.

Moderating effects of mentoring

Ettington (1998) indic ated that only a small number of studies have been conducted to examine moderators on the relationship between career plateau and outcome $v$ ariables. Some of the studies found that challenging job, perceived support from supervisors and coworkers (Chay, Aryee \& Chew, 1995; Ettington, 1998; MatSani, Maimunah \& Jegak, 2006), emotional intelligence and organizational support (Park \& Yoo, 2005), career motivation (Jung \& Tak, 2008), job characteristics (job autonomy and enrichment; Roger \& Tremblay, 1998) and mentoring others (Lentz \& Allen, 2009) acted as moderators of the relationship between perceived career plateau and outcome variables. In this study, mentoring others was selected as a moderator. Mentoring others is likely to play a moderating role in the relationship between career plateauing and work attitudes.

The moderating effects of mentoring in the plateauing-work attitude link is based on the career and life stage literature especially Levinson's life cycle theory. Levinson (1978) proposed four eras in the male life cycle: childhood and adolescence, early 
adulthood, middle adulthood and late adulthood. Within each era is a period of transition or adjustment that indicates the ending of an era and beginning of the next. In this study, the middle adulthood and mid-life transition were the focal point. Mid-life transition can be described as a period of change and reappraisal. It is a period when one examines one's contributions to the first half of the journey of life. It is a period that parallels the concepts of hierarchical and job content plateaving (Levinson, 1978). According to Levinson (1978), mid-life transition is a time for an employee to become a mentor and pass on a legacy in the form of family, work, or other subjectively valued contributions. The legacy fosters adult development and serves the purpose of enrichment and personal fulfillment (Lentz, 2004).

Reference, Stoner and Warren (1977) categorized employees into four typologies based on performance and potential promotion. The categorization is also called the life-cycle theory of plateauing. They are first learners or comers, individuals who possess high prospects for future advancement but are currently performing below acceptable standards. They are still learning and are not yet versed in the tasks of the organizations. Second, stars who are on the fast track career path, perform well and are self motivated. They possess a high potential for advancement and they are readily picked up by the management to hold important positions for future leadership.

Third, solid citizens are those who perform very well the bulk of organizational tasks but have little chance for future advancement due to very limited career path in the organization unless they opt for another career path after equipping the mselves with other professional qualifications (Maimunah,2008). They form the majority in an organization. They are needed in organizations for stability and continuity. If social citizens are treated passively or are denied access to development or challenging tasks, they will become de-motivated and become plateaved. Finally, the deadwoods are individuals who perform below the acceptable standards. These employees have problems for reasons of motivation and personal difficulties. Their number is very small in organizations but problems created by deadwoods could jeopardize the overall quality of service in organizations. Deadwoods are targets for remedial actions or risk of dismissal. They are also career plateaved. Solid citizens and deadwoods are plateaved employees. Solid citizens are effective while deadwoods are ineffective. Organizations should prevent solid citizens from slipping into the deadwood category.

Duffy (2000) applied chaos theory to conceptualize plateaved workers in order to reframe dominant issues faced by counsellors and clients. Chaos theory has been applied in career counselling organizational studies among career-workers. Chaos 
theory points to a period of transition in which change occurs in unpredictable, irregular and uncertain ways. The essence of chaos is change and it is not a stable condition or fixed state. It is a dynamic process that explains the changing relationship between entities in the organization. Duffy (2000) described the use of chaos theory by managers in dealing with plateaved employees. According to chaos theory, order can emerge from chaos and a new level of functioning can be achieved. Above all, there is need for management to understand and assess employees at each stage of their career and develop appropriate intervention to av oid career plateau. There is need for the mentoring of employees to recognize the type of career plateau employees are experiencing and develop various strategies to minimize it at the infancy stage.

Rotondo and Perrewe (2000) expanded Levinson's life cycle theory and explored mentoring others as a coping response to plateauing; they suggested that mentoring younger employees may help plateaved employees to cognitively manipulate the meaning of being plateaved. Result indicated that mentoring others was associated with higher levels of satisfaction, commitment and performance among plate aued employees.

Mid-life transition can mark a career plateau for many workers but mentoring can be an effective solution and coping mechanism that revitalizes and redirects one's knowledge and focus (Lentz, 2004; Rotondo \& Perrewe, 2000). Few studies have examined the moderator effects of mentoring others in plateauing-work attitudes link (Lentz, 2004; Lentz \& Allen, 2009; Jung \& Tak, 2008). Results of these studies have shown that mentoring others was associated with higher work satisfaction, commitment and job performance among plateaved employees. It is, therefore, expected that mentoring others will interact with career plateaving to predict positive work attitudes among employees. Thus, mentoring others will likely mitigate the negative effects of career plateauing, which may lead plateaved employees to higher job satisfaction and organizational commitment and reduce turnover intentions compared to employees with low levels of mentoring.

Hypotheses

The following hypotheses were tested,

$\mathrm{H}_{1}$ : Career plateaving will be negatively related to (a) job satisfaction and (b) organizational commitment.

$\mathrm{H}_{2}$ : Career plateauing will be positiv ely related to intentions to turnover.

$\mathrm{H}_{3}$ : Mentoring others will be positively related to (a) job satisfaction, and (b) organizational commitment. 
$\mathrm{H}_{4}$ : Mentoring others will be negativ ely related to intentions to turnover.

$\mathrm{H}_{5}$ : Mentoring others will moderate the relationship between career plateauing and (a) job satisfaction, (b) organizational commitment and (c) intentions to turnover such that for respondents having a higher level of mentoring, the relationship between career plateaving and each of job satisfaction, organizational commitment and intentions to turnover will be weaker.

\section{Methods}

Sample and procedure

Participants consisted of 280 (male $=150$, female $=130$ ) civil servants from one of the states in the middle belt of Nigeria. Respondents reported experience as a mentor. Their mean age was 38.64years (S.D=7.90) with ages ranging from 30 to 54 years. Education level of the participants ranged from diploma from University or post secondary school institutions to degree from university. The sample included a wide range of job titles and organizational levels. Examples of job positions are: senior nursing officers, principal nursing officers, chief nursing officers, senior education officers, principal education officers, vice-principals and principals. The organizational levels were staff, middle level management and senior management levels. The participants' working experience were 30 ye ars and above.

Six researchers assisted the present author in administering the questionnaire to the respondents during office hours. The purpose of this questionnaire was explained after the consent of the participants was obtained. The respondents were told not to write their names on the questionnaire to guarantee anonymity. They were assured that the information collected would be treated confidentiality. Initially, 300 questionnaires were distributed throughout the organizations that participated in the study. However, 280 questionnaires were properly filled and found useable for data analysis giving a response rate of $93.3 \%$. The data for this study was collected from the respondents between May and August 2008.

\section{Measures}

Demographic information was obtained from the participants through a form that requested for their ages in years (ordinal data), gender (nominal data) coded as male $=0$, female $=1$, job position (interval data) was coded as senior nursing/midwifery officers $=1$, principal nursing/ midwifery officers $=2$, chief nursing officers $=3$, senior education officers $=2$, principal education officers $=3$, chief education officers $=4$, Vice-Principals $=4$, Principals $=5$. Level of education included 
Diploma $=1$, first degree $=2$, Master's degree $=3$, Ph.D degree $=4$. Participants were asked for how long they have worked in their present job to get their tenure.

Career plateau. Career plateau was measured as a continuous multidimensional construct consisting of job content and hierarchical forms of plateauing. Job content plateauing was measured by means of six items from Milliman's (1992) career plateau scale. Responses were scored on a five-point scale ranging from Strongly Disagree $=1$ to Strongly Agree $=5$. Responses were scored such that higher scores indicated higher levels of job content plateauing. Examples of mentoring items are - job content plateauing - "I have an opportunity to learn and grow a lot in my current job"; "I expect to be constantly challenged in my job". Milliman (1992) reported an internal consistency of 0.87. In the present study, the Cronbach's coefficient alpha for job content plateau was 0.86. Six items from Milliman's (1992) career plateau scale were used to measure hierarchical plateauing. Responses were scored on a five point scale ranging from Strongly Disagree $=1$ to Strongly Agree $=5$. Responses were scored such that higher scores indicated higher levels of hierarchical plateaving. Hierarchical plateaving - "I expect to advance to a higher level in my company in the near future", "I have reached a point where I do not expect to move much in my company". Milliman (1992) reported an internal consistency of 0.90 . The Cronbach's coefficient alpha for the hierarchical scale in the present study was 0.88 .

Mentoring Provided. Career and psychosocial mentoring were assessed by a modified version of Noe's (1988) mentoring scale constructed by Lentz (2004). The items were modified to reflect the mentor's perspective. Participants who indicated having experience as a mentor were instructed to respond to these items based on their current or most recent mentoring relationship. Five items were used to assess career related mentoring. Examples of mentoring items are: As a mentor I "help my protégé finish assignment/tasks/projects or meet deadlines that otherwise would be difficult to complete", "help my protégé meet new colleagues", "give assignments that give my protégé the opportunity to learn new skills", "encourage my protege to prepare for advancement". Cronbach's alpha for these five items was 0.75. Ten items were used to assess psychosocial mentoring. The Cronbach's alpha was 0.83. A five-point Likert scale was used with responses ranging from strongly disagree $=1$ to strongly agree $=5$. Higher scores indic ated more mentoring provided. Noe (1988) reported internal consistency of .89 and .92 for career and psychosocial mentoring respectively. For this study, both career and psychosocial mentoring scales were summed together and used as an unidimensional scale. The Cronbach's alpha for the two scales used in the present study as a unidimensional scale was 0.78 . 
Job satisfaction. Job satisfaction was measured by three-item scale developed by Cammann, Fichman, Jenkins and Klesh (1983). This scale adopted a five-point scale with responses that ranged from Strongly Disagree $=1$ to Strongly Agree $=5$. Cronbach's alpha for this scale in this study was 0.85. Higher scores indicated higher job satisfaction.

Organizational Commitment. Organizational commitment was measured with the attitude commitment component, consisting of eight items developed by Allen and Meyer (1996). The scale was scored on a five-point scale that ranged from Strongly Disagree $=1$ to Strongly Agree $=5$. In this study, the Cronbach's alpha was 0.84. Higher scores indicated higher levels of organizational commitment.

Turnover Intentions. Four items developed by Lentz (2004) were used to measure turnover intentions i.e. intentions to leave the organization. Responses were scored on a five-point scale that ranged from Strongly Disagree $=1$ to Strongly Agree $=5$. Sample items were "I am currently looking for another organization to work for", "I often think of leaving this organization". Cronbach's alpha for this scale was 0.86 . Higher scores indicated higher intentions to leave the organization.

Control variables

Previous research has shown that gender, age, job tenure and job position may impact the mentoring relationship (Ragin \& Cotton, 1999) and plateaving (Stout, Slocum \& Cron, 1988). Therefore gender, age, tenure and job rank or positions were considered as potential control variables.

\section{Results}

Data analysis

Correlation analyses were conducted to examine the intercorrelations among all the variables included in the study. Hierarchical regression analyses were also conducted to test the moderating effect of mentoring on the relationship between perceived career plateau and the three dependent variables. To control the effects of demographic variables on the dependent variables, age, gender, tenure and job rank position were put into the regression equation at the first step. At the second step, perceived career plateau (job content and hierarchical plateaus) and mentoring were included in the regression equation. Finally, at the third step, the cross-product term of perceived career plateau and the moderator were put into the regression equation. 
Table 1 shows the means, standard deviations and intercorrelations among the variables used in this study.

Table 1: Means, standard deviations and intercorrelations among study v ariables

\begin{tabular}{|c|c|c|c|c|c|c|c|c|c|c|c|}
\hline Variables & 1 & 2 & 3 & 4 & 5 & 6 & 7 & 8 & 9 & 10 & 11 \\
\hline 1. Gender & - & & & & & & & & & & \\
\hline 2. Age & $.21^{*}$ & - & & & & & & & & & \\
\hline 3. Position & $.20 *$ & $.24^{*}$ & - & & & & & & & & \\
\hline 4. Tenure & .12 & $.40^{*}$ & $.25^{*}$ & - & & & & & & & \\
\hline 5. Education & .14 & $.23^{*}$ & $.26^{*}$ & $.20^{*}$ & - & & & & & & \\
\hline 6. J.C.Plateau & .70 & $.27^{*}$ & .17 & .18 & $.23^{*}$ & - & & & & & \\
\hline 7. H.Plateau & .05 & $.26^{*}$ & .18 & $.19^{*}$ & $.22 *$ & $.30^{*}$ & - & & & & \\
\hline 8. Mentoring & .09 & $.31^{*}$ & $.24^{*}$ & $.21^{*}$ & $.20^{*}$ & $-.22 *$ & -.07 & - & & & \\
\hline 9. J.Sat & & .12 & $.20^{*}$ & $.20^{*}$ & $.25^{*}$ & $.26^{*}$ & $-.26^{*}$ & $-.25^{*}$ & $.19^{*}$ & - & \\
\hline 10. O.C & & .18 & $.22 *$ & $.28^{*}$ & $.30 *$ & $.19^{*}$ & $-.30 *$ & $-.24^{*}$ & $.20^{*}$ & $.37^{*}$ &.- \\
\hline 11. T.I & & .10 & $-.19^{*}$ & $.21^{*}$ & $-.26^{*}$ & $.20^{*}$ & $.32^{*}$ & $\begin{array}{ll}.27^{*} & -.21\end{array}$ & & $\begin{array}{ll}-.32 & -.40\end{array}$ & * \\
\hline Mean & - & 38.64 & 2.73 & 13.87 & 2.56 & 2.56 & 3.62 & 7.83 & 3.86 & 3.57 & 1.85 \\
\hline SD & - & 7.90 & 1.20 & 6.45 & 2.30 & .74 & .89 & .62 & .73 & .65 & .94 \\
\hline
\end{tabular}

Note: .J.C. Plateau= Job Content Plateau, H.Plateau= Hierarchical Plateau ,J.Sat=Job Satisfaction, O.C. = Organizational Commitment, S.D.=Standard Deviations, Gender (0=Male, $1=$ Female), T.I = Turnover Intentions, Tenure (Years Served in present job in the organization ). $* P<0.05$.

Results on Table 1 indicate that job content plate auing was negatively related to job satisfaction ( $r=-.26, p<.05)$, and organisational commitment $(r=-.30, p<.05)$. Hierarchical plateauing was significantly related to job satisfaction $(r=-.25, p<.05)$ and organisational commitment $(r=-.24, p<.05)$. Therefore, Hypotheses la-b received support.

Hypothesis 2 predicted a positive relationship between career plateauing and turnover intentions. Job content plateauing was positively related to turnover intentions $(r=.32, p<.05)$. Similarly, hierarchical Plateauing was positiv ely related to turnover intentions $(r=.27, p<.05)$. Therefore, Hypothesis 2 also received support.

Hypothesis 3a-b predicted that mentoring will be positively related to job satisfaction and organisational commitment. Results indicated that mentoring was significantly related to job satisfaction $(r=.19, p<.05)$, organisational commitment $(r=.20, p<.05)$ and negatively related turnover intentions $(r=-.21, p<.05)$. Therefore, hypotheses 3 and 4 were fully supported. 
Table 2: Results of Hierarchical Regression Analyses for testing mo derating effects of mentoring for job satisfaction and organizational commitment

\begin{tabular}{|c|c|c|c|c|c|c|c|c|c|c|}
\hline \multicolumn{4}{|c|}{ Job Satisfaction } & \multicolumn{6}{|c|}{ Organization Commitment } & \\
\hline Variable & $\mathbf{R}^{2}$ & $\Delta \mathbf{R}^{2}$ & $\Delta \mathbf{F}$ & $\beta$ & df & $\mathbf{R}^{\mathbf{2}}$ & $\Delta \mathbf{R}^{2}$ & $\Delta \mathbf{F}$ & $\beta$ & df \\
\hline Step.1 & .06 & - & $5.84^{*}$ & & $5 / 275$ & .13 & - & $4.55^{*}$ & & $5 / 275$ \\
\hline Gender & & & & & .07 & & & & & .0 \\
\hline Age & & & & $.17^{*}$ & & & & & $.16^{*}$ & \\
\hline Position & & & & $.15^{*}$ & & & & & $.17^{*}$ & \\
\hline Tenure & & & & $.13^{*}$ & & & & & $.15^{*}$ & \\
\hline Education & & & & $.14^{*}$ & & & & & $.13^{*}$ & \\
\hline Step.2 & .32 & .22 & $8.56^{*}$ & & $3 / 272$ & .37 & .24 & $6.97^{*}$ & & $3 / 272$ \\
\hline J.C. Plateau & & & & $-.34^{*}$ & & & & & $-.25^{*}$ & \\
\hline H. Plateau & & & & $-.28^{*}$ & & & & & $-.28^{*}$ & \\
\hline Mentoring & & & & $.22 *$ & & & & & .11 & \\
\hline $\begin{array}{l}\text { Step.3 } \\
\text { Interactions }\end{array}$ & .35 & .03 & $10.75^{*}$ & & $2 / 270$ & .38 & .01 & $9.64^{*}$ & & $2 / 270$ \\
\hline J.C. Plateau & Ment. & & & $.23^{*}$ & & & & & .08 & \\
\hline H. Plateau $x$ & lent. & & & $.19^{*}$ & & & & & .19 & \\
\hline
\end{tabular}

Note: J.C. Plateau= Job Content Plateau, H. Plateau= Hierarchical Plateau, Ment=Mentoring. $P<0.05$.

Hypotheses $5 \mathrm{a}-\mathrm{c}$ posited significant interactions between mentoring and plateau variables to predict work attitudes. As shown in Table 2, the interaction between mentoring and job content plateauing $(\beta=.23$. $p<.05)$ and that between mentoring and hierarchical plateaving $(\beta=.19, p<.05)$ for job satisfaction were significant. The interaction between mentoring and job content plateaving $(\beta=.08, p>.05)$ and that between hierarchical plateaving and mentoring for organizational commitment $(\beta=.10, p>.05)$ were not significant. Hypotheses $5 b$ did not receive support.

Table 3: Results of Hierarchical Regression Analyses for testing mo derating effects of mentoring for turnover intention

\begin{tabular}{|c|c|c|c|c|c|}
\hline \multirow[t]{2}{*}{$\overline{\text { Variable }}$} & \multicolumn{3}{|c|}{ Turn over Intentions } & \multirow[b]{2}{*}{$\beta$} & \multirow[b]{2}{*}{$d f$} \\
\hline & $\mathrm{R}^{2}$ & $\Delta \mathrm{R}^{2}$ & $\Delta \mathrm{F}$ & & \\
\hline Step.1 & .06 & - & $5.30^{*}$ & & $5 / 275$ \\
\hline Gender & & & & .05 & \\
\hline Age & & & & $.14^{*}$ & \\
\hline Position & & & & $.16^{*}$ & \\
\hline Tenure & & & & $.15^{*}$ & \\
\hline Education & & & & $.17^{*}$ & \\
\hline Step.2 & .34 & .28 & $9.80^{*}$ & & $3 / 270$ \\
\hline J.C. Plateau & & & & $.38^{*}$ & \\
\hline H. Plateau & & & & $.32^{*}$ & \\
\hline Mentoring & & & & $.28^{*}$ & \\
\hline
\end{tabular}




\begin{tabular}{|c|c|c|c|c|}
\hline Step.3 & .36 & .02 & $10.24^{*}$ & \\
\hline J.C.Plateau X Ment & & & & $.30^{*}$ \\
\hline H. Plateau X Ment & & & & $.27^{*}$ \\
\hline
\end{tabular}

Note: J.C. Plateau =Job Content Plateau, H. Plateau= Hierarchical Plateau, Ment $=$ Mentoring, ${ }^{*}=$ $p<0.05$.

Finally, as shown in Table 3, the interaction between mentoring and job content plateaving $(\beta=.30, p<.05)$ and that between mentoring and hierarchical plateauing $(\beta=.27, p<.05)$ for turnover intentions were significant. To show the nature of the moderating effects of mentoring, regression lines between each career plateaving and the two dependent variables (job satisfaction and turnover intentions) were drawn at the high and lows levels of mentoring. The relationships between each career plateaving and the two dependent variables were significantly weaker for the high level mentoring group. This indicated that Hypotheses 5 a\&c received support.

\section{Discussion}

The purpose of this study was to examine the effects of career plateauing on job satisfaction, organizational commitment and turnover intentions and the moderating effects of mentoring on the relationship between career plateaving and each of the three dependent variables. The results show that career plateau (job content and hierarchical) was negatively related to job satisfaction and organizational commitment and was positively related to turnover intentions. Mentoring has moderating effects on the relationship between career plateauing and job satisfaction and turnover intentions.

Negative relationships were found between career plateauing and job satisfaction (Jung \& Tak, 2008; Lee, 2004; Lentz, 2004; Lentz \& Allen, 2009. McCleese \& Eby, 2006; Xie \& Long, 2008) and organizational commitment (Jung \& Tak, 2008; Lee, 2004; Lentz, 2004; Lentz \& Allen, 2009; McCleese \& Eby, 2006). Career plateauing was positiv ely related to turnover intentions and this is consistent with the w ork of previous researchers who reported similar findings (Heilman, Holt \& Rilovick, 2008; Lentz, 2004). One explanation for the findings from this study could be that career plateaved employees became frustrated and they are not motivated to continue to work harder. They might have reasoned that the efforts they put into their work in the organization were not rewarded and as such their work may not be interesting to them, which leads to job dissatisfaction. They may not be committed to the cause of the organization as they were before being plateaved and they might be prepared 
to take up jobs with ranks higher than their present ranks any time the opportunity presents itself.

Results from this study also indicated that mentoring others was significantly and positively related to job satisfaction and organization commitment but negatively related to turnover intentions. These results are in agreement with the work of other researchers who reported similar findings (Allen et al., 2004; Lentz, 2004; Lentz \& Allen, 2009; Levenson et al., 2006; Ragins et al., 2000). An explanation for these findings is that mentoring others has some benefits such as having higher motivation and selffulfillment for seeing someone guided or coached by us growing. This assists the mentor in developing more positive work attitudes.

Findings from this study showed that mentoring others play a significant role in moderating the relationship between career plateaving and job satisfaction and turnover intentions. These findings support the work of previous researchers who obtained similar results (Lentz, 2004; Lentz \& Allen, 2009; Rotondo \& Perrewe, 2000). Reasons for these findings could be that the period of career plateauing parallels that of middle adulthood and the mid-life transition when the individual wishes to pass on a legacy in the form of work, family or other subjectively valued contributions. When a plateaved employee is able to pass on his/her contributions to others in the form of mentoring he/she becomes satisfied. This legacy fosters adult development and serves the purpose of enrichment and personal fulfillment. Mentoring others is a coping response to plateaving and it contributes to limit the negative consequences associated with career plateauing.

That mentoring others did not mo derate the relationship between career plateaving and organizational commitment was surprising and contradicted the work of previous researchers who found, on the contrary, that mentoring others moderated the relationship between plateauing and organizational commitment (Jung \&Tak, 2008; Lentz, 2004). This result means that with mentoring others the negative relationship between career plateaving and organizational commitment still exists. That is, the negative effect of plateauing has not been alleviated by mentoring others. The reason for mentoring others not moderating the negative relationship between career plateauing and organizational commitment could be because the employees had become frustrated, disinterested and dissatisfied with their work. They might also have felt that an organization that has deprived them of promotion or advancement in their work does not deserve being committed to or attached to. As such, the negative relationship between career plateauing and organizational commitment is not affected by mentoring others. 
Implications of the findings

Findings from this study have theoretical and practical implications. The theoretical implications are in terms of showing that career plateaving has a negative impact on job satisfaction and organizational commitment and aids turnover intentions and that mentoring others can alleviate the negative impacts of career plateauing on work attitudes. Therefore, more research should be conducted on identifying the symptoms of career plateauing and moderating variables to reduce the negative impact of career plateauing on work outcome variables.

This study has practical implications for motivating career plateaved employees in the organizations. Since career plateaving has a negative impact on work attitudes such as job satisfaction and organizational commitment and encourages turnover intention, organizations should reduce the level of career plateauing by transforming or enriching jobs, facilitating lateral or cross-functional moves and providing honest feedback to employees. This will enable the employees to acquire the necessary knowledge and skills for them to position themselves for opportunities elsewhere if promotion is blocked in their present organization. Because mentoring others helps in alleviating the negative effect of career plateauing on job satisfaction and turnover intentions, organizations should develop formal mentoring programmes to increase individuals' career motivation, job satisfaction and organizational commitment. Employees may report more organizational commitment when the mentor role is sponsored by the organization. Organizations should identify causes of career plateauing and develop appropriate interventions to manage it at the infancy stage. In addition, employees should be counselled by counselling psychologists and made aware that in this era of globalization, "career advancement" is being replaced with "career achievement". Also management should provide counselling and placement services for those employees who decide to quit the organizations.

Limitations and Future Rese arch

Some limitations of this study should be mentioned. Firstly, this study is cross-sectional in nature and as such it is not possible to infer causality. A longitudinal study design in future research would allow cause-and-effect relationship to be established and would allow us to examine changes in the study variables across time. A second limitation is that the present study used government employees because of the prevalence of plateau in government agencies. Future research could include employees in the private sectors to confirm the generalizability of the findings in private organizations. This could allow researchers to compare government and 
private sector employees on the relationship between career plateaving and work attitudes.

A third limitation of this study is that self-report measures were used in obtaining data from the respondents. There could have been some response biases when the respondents were filling the questionnaires. In order to check for these response biases future research could include interview information. Furthermore, no performance data was collected from respondents. This has limited the information about work outcomes to attitudinal dimensions leaving out behavioural aspects. As such, future research should include work performance data.

Also, there is need to carry out more research on why individuals would want to engage in a mentor role because mentoring could be seen as a type of organizational citizenship behaviour. Furthermore, future research should try to determine the perception of career plateaved employees on the reasons for which they think they have been plateaved. This could allow future researchers to find out employees for whom career plateauing effects had been positive or negative. These effects could be used as moderator variables in the relationship between career plate auing and work attitudes. Moreover, job autonomy and job enrichment could be used as moderator variables in the investigation of the relationship between career plateauing and work outcomes.

\section{Conclusion}

Despite these limitations, this study has provided evidence that relationships exist between career plateauing and work attitudes and that mentoring others serves as a significant moderator of the relationships. The unique contribution of this study is that it is the first to examine empirically the moderating role of mentoring others in the relationship between career plateauing and work attitudes among civil servants in Nigeria. This study provided evidence for the benefits of mentoring for the mentors because the findings revealed that, by mentoring others, career plateaved employees had increased job satisfaction and reduced turnover intentions. This study also contributed to the literature on career plateauing and mentoring because it has shown an important method of improving the work attitudes of career plateaved employees through mentoring others. 


\section{References}

Allen, N.J. \& Meyer, J.P. (1996). Affective, continuance and normative commitment to the organization: An examination of construct validity. Journal of Vocational Behaviour, $49,(2), 252-276$.

Allen, T.D., Eby, L.T., Poteet, M.L., Lentz, E. \& Lima, L. (2004). Career benefits associated with mentoring for protégés: A meta-analysis. Journal of Applied Psychology, 89, (1), 127136.

Allen, T.D.; Poteet, M.L \& Burroughs, S.M. (1997). The mentor's perspective: A qualitative inquiry and future research agenda. Journal of Vocational Behaviour, 5(1), 70-89.

Allen,T.D.,lentz, E. \& Day, R.(2003). Career Success Outcomes and Attitudes Associated with Mentoring Others, Papers presented at the $18^{\text {th }}$ annual of the society for Industrial and Organizational Psychology, Orlando, FL.

Armstrong- Stassen, M. (2008). Factors associated with job content plateauing among older workers. Career Development International , 13(7), 594-613.

Bardwick, J, M. (1986). The plateauing Trap. Bantam Books, Toronto, PP.17-164.

Bozionelos, N.(2004). Mentoring provided: Relation to mentor's career success, personality and mentoring received. Journal of Vocational Behaviour, 64 (1), 24-46.

Burke, R.J \& Mckeen, C.A. (1997). Benefits of mentoring relationship among managerial and professional women: A cautionary tale. Journal of Vocational Behaviour; 51 (1), 4357.

Burke, R.J. \& Mikkelsen, A. (2006). Examining the career plateau among police officers. International Journal of Police Strategies and Management, 29(4), 691-703.

Burke,R.J.(1984). Mentors in organizations, Group and Organization Studies, 9,353-372.

Cammann, C., Fichman,M., Jenkins, D. \& Klesh, J. (1983). Assessing the attitudes and perception of organizational members. In S.Seashore, E. Lawlerm, P. Mirvis \& C. Cammann (Eds.) Assessing organizational change: A guide to methods, measure and practice, (p.84). New York: Wiley. 
Chay,Y.W.; Aryee's. \& Chew, I.(1995).Career plateauing reactions and moderator among managerial and professional employees. International Journal of Human Resources Management, 6(1), 61-78.

Clark, J.W. (2005). Career plateaus in retail management. Proceedings of the Annual Meeting of the Association of Collegiate Marketing Educators, (2005), PP.77-84. Retrieved 17th November 2009 from http://sbaer.uca.edu/research/acme/2005/09.pdf.

Eby,L.T.;Allen,T.D;Evans,S.C.;Ng,T.\&Duboi,D.L.(2008).Does mentoring matter? A multidisciplinary meta-analysis comparing mentored and non- mentored individuals. Journal of Vocational Behaviour, 72(2), 254-267.

Ettington, D.R. (1998). Successful career plateauing. Journal of Vocational Behaviour, 52 (1), $72-88$.

Feldman, D.C.\&Weitz, B.A.(1988). Career plateaus reconsidered. Journal of Management, 14(1), 69-80.

Fowler, J. (2002). Mentoring relationship at work: An investigation of mentoring function, benefits and gender. Doctors of Philosophy Thesis. School of Applied Psychology, Faculty of Health Science Griffith University,

Heilmann, S.G, Holt, D.T. \& Rilovick, C.Y. (2008). Effects of career plateauing on turnover: A test of a model. Journal of Leadership \& Organizational studies, August 2008. Retrieved 3rd November 2009 from

http:/wWw.enterpreneur.com/tradejournals/article/182035190_2.html.

Jung, J. \& Tak, J. (2008). The effects of perceived career plateau on employees' attitudes: Moderating effects of career motivation and perceived supervisor support with Korean employees. Journal of Career Development, 35(2), 187-201

Kram, K.E. (1985). Mentoring at work, Glenview, IL: Scott, Foresman and Company.

Kreuter, E.A (1993). Why Career plateaus are healthy. The CPA Journal Online, October, 1993 http://wwww.nysscpa.org/cpajournal.

Laukau,M.J. \& Scandura, T.A. (2002). An investigation of personal learning in mentoring relationships: Contents, antecedents and consequences. Academy of Management Journal, 45(4), 779-790. 
Lee, K. (2004). The relationship between employees' perception of career plateau and job attitudes Korean Association of Business Education, 35, 193-213.

Lentz, E. \& Allen, T.D.(2009). The role of mentoring others in the career plateauing phenomenon. Group \& Organizational Management, 34 (3), 358-384.

Lentz, E. (2004). The link between the career plateau and mentoring-Addressing the empirical gap, M.A. Thesis, Department of Psychology, College of Arts and Sciences, University of South Florida.

Levenson, A.R., Van der Stede, W.A. \& Cohen, S.G. (2006). Measuring the relationship between managerial competencies and performance. Journal of Management, 32 (3), 360-380.

Levinson, D.J. (1978). The season of a man's life, New York: Alfred A. Knopf.

Maimunah, I.(2008).Career Plateau: Constructs, consequences and coping strategies. European Journal of Social Sciences, 5(4), 111 -120.

Mat Sani,H., Maimunah, I. \& Jegak, U.(2006). Moderating role of job performance on the relationship between career plateauing and work outcomes among administrative and diplomatic officers in Malaysia. The Journal of Global Business Management, 2(3), 12-18.

McCleese, C, S., Eby, L.T., Scharlau, E.A. \& Hoffman, B.H. (2007). Hierarchical, job content of stress, depression and coping responses. Journal of Vocational Behaviour, 71 (2), 282299.

McCleese, C.S. \& Eby, L.T. (2006). Reactions to job content plateaus: Examining role ambiguity and hierarchical plateau as moderators. The Career Development Quarterly, $55,64-76$.

Milliman, J.F. (1992). Causes, consequences and moderating factors of career plateauing, Unpublished doctoral dissertation, University of Southern California.

Noe, R.A. (1988). An investigation of the determinants of successful assigned mentoring relationship. Personnel Psychology, 41 , (3), 457-479.

Ongori, H. \& Agolla, J.E. (2009) Paradigm shift in managing career plateau in organization: The best strategy to minimize employee intention to quit. Africa Journal of Business Management, 3(6), 268-271. 
Palmero, S., Roger, A. \& Tremblay, M. (2001). Work satisfaction and career plateau of part-time workers. EGOS 17th Colloquium Lyon, 2001, Sub-Theme 14 (Career as professional Odyssey). Retrieved $13^{\text {th }}$ November 2009 from http://centremagellan.univIyon3.fr/fr/articles/88-567.pdf.

Park, G. \& Yoo, T. (2005). The impact of career plateau on job and career attitudes and moderating effects of emotional intelligence and organizational support. Korean Journal of industrial and organizational Psychology, 18,499-523.

Ragins, B.R. \& Scandura, T.A. (1999). Burden or blessings? Expected costs and benefits of being a mentor. Journal of Organizational Behaviour, 20(3) 493-509.

Ragins, B.R. \& Cotton, J.L. (1999). Mentoring functions and outcomes: A comparison of men and women in formal and informal mentoring relationship. Journal of Applied Psychology, 84, (4), 529-548.

Ragins, B.R., Cotton, J.L. \& Miller, J.S. (2000). Marginal mentoring: The effects of type of mentor, quality of relationship and programme design on work and career attitudes. Academy of Management Journal , 43(6), 1177-1194.

Roger, A. \& Tremblay, M. (2009). The moderating effect of job characteristics on managers' reactions to career plateau. Retrieved $13^{\text {th }}$ November 2009 from http:ideas.repec.org/p/cir/cinwor.98s-27.html.

Rogers .A. \&Tremblay, M. (1998). The moderating effect of job characteristics on managers' reactions to career plateau. Retrieved 13th Nov.2009 from http.//ideas.repec.org/p/cir/cirwor/985-27.html.

Rotondo, D.M. \& Perrewe, P.L. (2000). Coping with a career plateau: An empirical examination of what works and what doesn't. Journal of Applied Social Psychology, 30 , 2622-2646.

Salami, S. O. (2010). Mentoring and work attitudes among nurses: The moderator roles of gender and social support. Europe's Journal of Psychology, 1, 102-126.

Stout, S.K., Slocum, J.W. \& Cron, W.L. (1988). Dynamics of the career plateauing process. Journal of Vocational Behaviour, 32(1), 74-91.

Tremblay, M. \& Roger, A. (2004). Career plateauing reactions: The moderating role of job scope, role ambiguity and participating among Canadian managers. International Journal of Human Resource Management, 15(6), 996-1017. 
Tremblay,M., Roger,A. \& Toulouse, J.M.(1995). Career plateau and work attitudes: An empirical study of managers. Human Relations, 48 (3), 221-237.

Underhill,C.M.(2006). The effectiveness of mentoring programmes in corporate settings: A meta-analytical review of the literature. Journal of Vocational Behaviour, 68 (2), 292-307.

Van Emmerik, I.J.H. (2008). It is not only mentoring: the combined influences of individuallevel and team-level support on job performance. Career Development International, $13(7), 575-593$.

Xie, B. \& Long, L. (2008). The effects of career plateau on job satisfaction, organizational commitment and turnover intentions. Acta Psychological Sinica, 40(8), 927 -938.

Zey, M.G. (1991).The mentor connection: Strategic alliances in Corporate Life, New Jersey: Transaction Publishers.

\section{About the author}

Dr Samuel O. Salami received his PhD from the University of Ilorin, Ilorin, Nigeria. He is a Senior Lecturer in Counselling Psychology at the Department of Guidance and Counselling, University of Ibadan, Ibadan, Nigeria but currently on sabbatical leave at the Kampala International University, Kampala, Uganda. His research interest includes mentoring, leadership, employee commitment, job attitudes, career development, organizational conflict resolution and occupational stress. His research has been published in Europe's Journal of Psychology, European Journal of Scientific Research, Career Development International Journal, Journal of Workplace Learning, Women in Management Review and International Journal for the Advancement of Counselling, Social Behaviour and Personality, The Journal of International Social Research, US-China Education Review and Perspectives in Education.

Address for correspondence: Department of Guidance and Counseling, Kampala International University, Kampala 256, Uganda

E-mail: drsosalami2002@yahoo.co.uk 